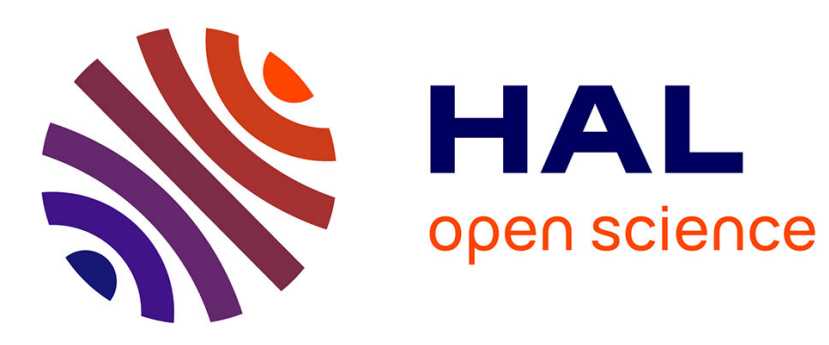

\title{
Ethylenedithio-Tetrathiafulvalene-Helicenes: Electroactive Helical Precursors with Switchable Chiroptical Properties
}

Thomas Biet, Arnaud Fihey, Thomas Cauchy, Nicolas Vanthuyne, Christian Roussel, Jeanne Crassous, Narcis Avarvari

\section{To cite this version:}

Thomas Biet, Arnaud Fihey, Thomas Cauchy, Nicolas Vanthuyne, Christian Roussel, et al.. Ethylenedithio-Tetrathiafulvalene-Helicenes: Electroactive Helical Precursors with Switchable Chiroptical Properties. Chemistry - A European Journal, 2013, 19 (39), pp.13160-13167. 10.1002/chem.201301095 . hal-01086724

\section{HAL Id: hal-01086724 https://hal.science/hal-01086724}

Submitted on 2 Jun 2016

HAL is a multi-disciplinary open access archive for the deposit and dissemination of scientific research documents, whether they are published or not. The documents may come from teaching and research institutions in France or abroad, or from public or private research centers.
L'archive ouverte pluridisciplinaire HAL, est destinée au dépôt et à la diffusion de documents scientifiques de niveau recherche, publiés ou non, émanant des établissements d'enseignement et de recherche français ou étrangers, des laboratoires publics ou privés. 
Ethylenedithio-tetrathiafulvalene-helicenes: electroactive helical precursors with switchable chiroptical properties

Thomas Biet, ${ }^{[\mathrm{a}]}$ Arnaud Fihey, ${ }^{[\mathrm{a}]}$ Thomas Cauchy, ${ }^{[\mathrm{a}]}$ Nicolas Vanthuyne, ${ }^{[\mathrm{b}]}$ Christian Roussel, ${ }^{[\mathrm{b}]}$ Jeanne Crassous, ${ }^{*[\mathrm{c}]}$ and Narcis Avarvari*[a]

[a] Dr. T. Biet, A. Fihey, Dr. T. Cauchy, Dr. N. Avarvari Université d'Angers, CNRS UMR 6200

Laboratoire MOLTECH-Anjou, 2 bd Lavoisier, 49045 Angers (France)

Fax: (+33)0241735405

E-mail: narcis.avarvari@univ-angers.fr

[b] Dr. N. Vanthuyne, Prof. C. Roussel iSm2 UMR 7313

Aix Marseille Université, CNRS, 13397 Marseille (France)

[c] Dr. J. Crassous

Institut des Sciences Chimiques de Rennes, UMR 6226

CNRS- Université de Rennes 1

Campus de Beaulieu, 35042 Rennes Cedex (France)

E-mail: jeanne.crassous@univ-rennes1.fr 
Abstract: Electroactive fused ethylenedithio-tetrathiafulvalene-[4]helicene and -[6]helicenes have been synthesized through a strategy involving the preparation of 2,3-dibromo-helicene derivatives as intermediates. The dihedral angles between the terminal helicenes, as determined by single crystal X-ray analyses, amount to $22.7^{\circ}$ and $50.7^{\circ}$ for the [4] helicene and [6]helicene, respectively. The solid state architectures show interplay between S $\cdots S$ and $\pi \cdots \pi$ intermolecular interactions. The chiroptical properties of the enantiopure EDT-TTF[6]helicene derivatives have been investigated and supported by TD DFT calculations. Remarkable redox switching of the circular dichroism signal between the neutral and radical cation species has been achieved.

\section{Keywords:}

chirality, helicenes, tetrathiafulvalenes, crystal structures, chiroptical properties 


\section{Introduction}

The chemistry and physico-chemical properties of $[n]$ helicenes, whose peculiar screwshaped skeleton results from the ortho-condensation of more than 5- or 6-membered aromatic rings, ${ }^{[1]}$ continuously stimulate considerable interest. ${ }^{[2]}$ Indeed, their inherent helical chirality confers to carbo- and heterohelicenes, ${ }^{[3]}$ as well as to metal containing derivatives of the latter, ${ }^{[4]}$ excellent chiroptical properties, such as huge optical rotations and strong circular dichroism activity, ${ }^{[5]}$ making them valuable functional precursors for applications such as nonlinear optics, ${ }^{[6]}$ luminescent materials, ${ }^{[4 b, 7]}$ or, possibly, chiral wave guides. ${ }^{[8]}$ Moreover, much effort is currently devoted toward the modulation of the chiroptical properties of helicenes upon irradiation or redox processes in the case where photo- ${ }^{[9]}$ or electroactive ${ }^{[10]}$ units are present in their structure, yet in these both reported systems the helicenic unit is not preserved in one of the commutable states. For example, in the latter, ${ }^{[10]}$ a chiroptical redox switch was achieved between dihydro[5] helicenes and dicationic binaphtyl species upon reversible breaking of a $\mathrm{C}-\mathrm{C}$ bond triggered by electron transfer. Examples of electroactive helicenes ${ }^{[11]}$ with redox tunable chiroptical response are still extremely rare in the literature. Redox modulation of the CD signal with retention of the helicenic skeleton was evidenced by Rajca et al. in the case of a thia[7]helicene derivative whose chemical oxidation provided a configurationally stable radical cation. ${ }^{[12]}$ More recently, Autschbach, Crassous, Réau et al. described the chiroptical electrochemical redox switching behavior of a [6]helicene decorated with a vinyl ruthenium (II) electroactive unit. ${ }^{[13]}$

Tetrathiafulvalene (TTF) represents a prominent electroactive unit which was investigated over the years in diverse fields of application, ${ }^{[14]}$ and especially as precursors for organic conductors and superconductors. ${ }^{[15]}$ A relatively recent direction of research consists in the introduction of chiral information in TTF derivatives with the main objectives to access chiral conductors ${ }^{[16]}$ or chiral electroactive ligands. ${ }^{[17]}$ The efforts directed toward the preparation of TTF based chiral conductors are motivated, besides the modulation of the structural

disorder ${ }^{[18]}$ by the possible existence of the electrical chiral-anisotropy effect, ${ }^{[19]}$ which was experimentally evidenced in the case of chiral carbon nanotubes, provided with helical chirality. ${ }^{[20]}$ Thus, the association of helicenes with donor TTF units within fused heliceneTTFs appears to be very attractive in order to access inherent helical electroactive precursors which are prone to show redox tunable chiroptical properties. Moreover, the occurrence of chiral helical packings in the solid state represents a most promising perspective towards the 
preparation of helical conducting salts. We describe herein the straightforward synthesis of the first reported TTF-helicene derivatives, in which ethylenedithio-tetrathiafulvalene (EDTTTF) is fused to [n]helicene ( $n=4$ or 6 ) units. This unprecedented family of TTF based helical electroactive precursors presents several remarkable aspects: $i$ ) access to helical dithiolene intermediates through sequential functionalization of the helical backbone; ii) redox tunable chiroptical properties through the formation of stable radical cation species; and iii) huge potential for the preparation of crystalline helical conducting materials. Furthermore, this molecular engineering of helicene-fused TTF derivatives enables to take benefit from the helicene chemistry to prepare extended $\pi$-conjugated TTF derivatives with unprecedented topology.

\section{Results and Discussion}

Synthesis and characterization: For the synthesis of TTF[n]helicene derivatives we have envisioned the construction of the protected dithiolates $\mathbf{4 a - b}$ as key intermediates by accessing first the unprecedented functional dibromo-[4] and [6]helicenes 3a-b (Scheme 1). These latter have been synthesized by Wittig reaction between the in situ generated ylides from the phosphonium salts $\mathbf{1 a - b}$ and the appropriate 3,4-dibromobenzaldehyde, providing the stilbenic derivatives $\mathbf{2 a - b}$ as cis/trans mixtures, which were subsequently engaged in the classical oxidative photocyclization. ${ }^{[1 \mathrm{a}, 2]}$ Note that the photochemical process appears to be highly stereoselective since the cyclization occurred at one position only.

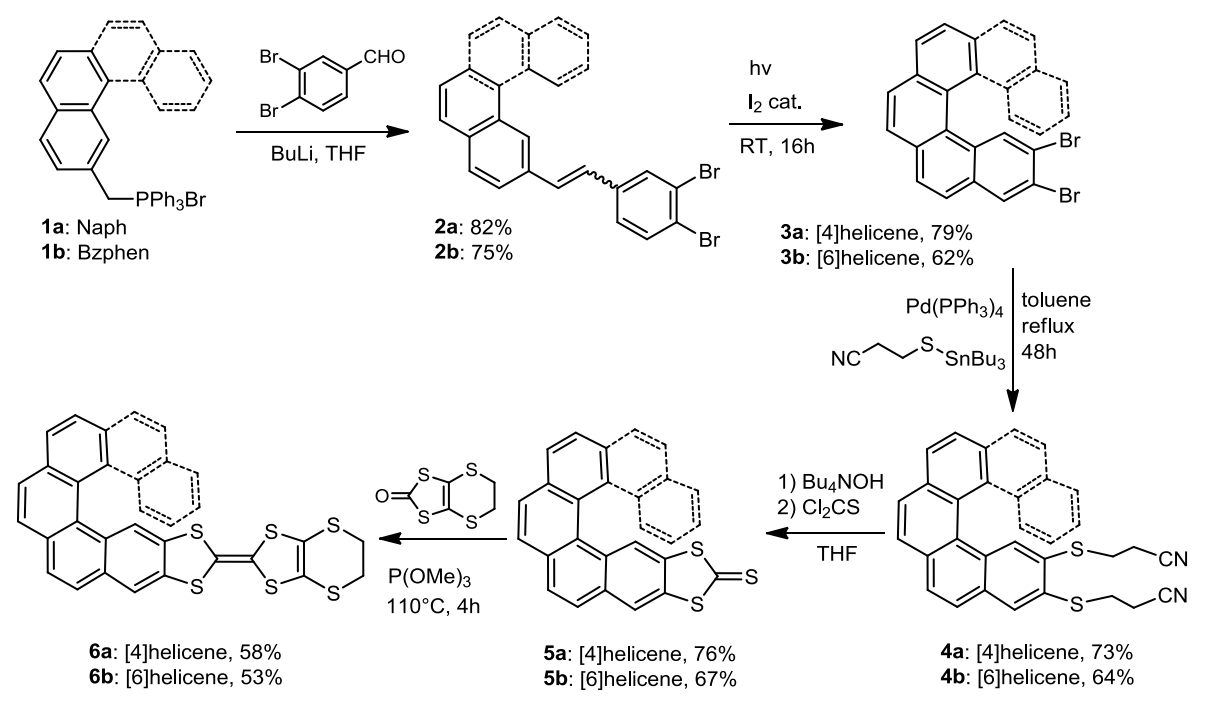

Scheme 1. Synthesis of TTF-helicenes 6a-b. 
The [4] helicene $\mathbf{3 a}$ is obtained as a pale yellow oil, while the 2,3-dibromo[6] helicene $\mathbf{3 b}$ is isolated as a white solid, for which suitable single crystals have been obtained by recrystallization in a $\mathrm{CH}_{2} \mathrm{Cl}_{2} /$ hexane $(2: 1)$ mixture. The $\mathrm{X}$-ray analysis shows that $\mathbf{3 b}$ crystallizes as conglomerate, ${ }^{[21]}$ with each enantiomer crystallizing separately in the noncentrosymmetric space group $P 22_{1} 2_{1} 2_{1}$ of the orthorhombic system. ${ }^{[22]}$ The helical curvature (hc), representing the dihedral angle between the terminal helicene rings, amounts to $47.9^{\circ}$, a value in the usual range for [6]helicenes. ${ }^{[3 \mathrm{~b}, 4 \mathrm{~d}]}$ Note that the $(M)$-2-monobromo[6]helicene, also crystallizing in the $P 22_{1} 2_{1}$ space group, presents a he value of $52.3^{\circ}{ }^{[23]}$ The two enantiomers of $\mathbf{3 b}$ could be separated by chiral HPLC, which allowed the assignment of their specific rotations $\left([\alpha]_{\mathrm{D}}^{25}=+2273 \pm 1 \%,[\phi]_{\mathrm{D}}^{25}=+11035 \pm 1 \%{ }^{\circ} \mathrm{cm}^{2} / \mathrm{dmol}\right.$ for $(P)-3 \mathbf{b}$ and the respective negative values for $(M)-3 \mathbf{b})$, in agreement with the absolute configurations and rotations determined for the carbo[6]helicene and 2-bromo[6]helicene. ${ }^{[23]}$ However, the subsequent synthetic steps have been performed on the racemic 3b. The Stille type coupling reaction between $\mathbf{3 a}-\mathbf{b}$ and the $\mathrm{Bu}_{3} \mathrm{Sn}$-thiopropionitrile derivative ${ }^{[24]}$ afforded the propionitrile protected dithiolates $\mathbf{4 a - b}$, which were further transformed, upon base mediated deprotection followed by reaction with thiophosgene, into the helical dithiolethiones $\mathbf{5 a - b}$, isolated as yellow solids. These latter represent convenient "half"-TTF precursors to access various TTFhelicenes, while the dithiolates resulting from the deprotection of $\mathbf{4 a - b}$ are also valuable ligands for helical metal-dithiolene complexes. The single crystal X-ray structure of the functionalized [4]helicene 5a was determined for both enantiomers, since they form crystalline conglomerate by recrystallization in toluene. Accordingly, both $(M)$ and $(P)-5 \mathbf{a}$ crystallize in the monoclinic non-centrosymmetric space group $P 2_{1}$, with one independent molecule in the unit cell (Figure 1).

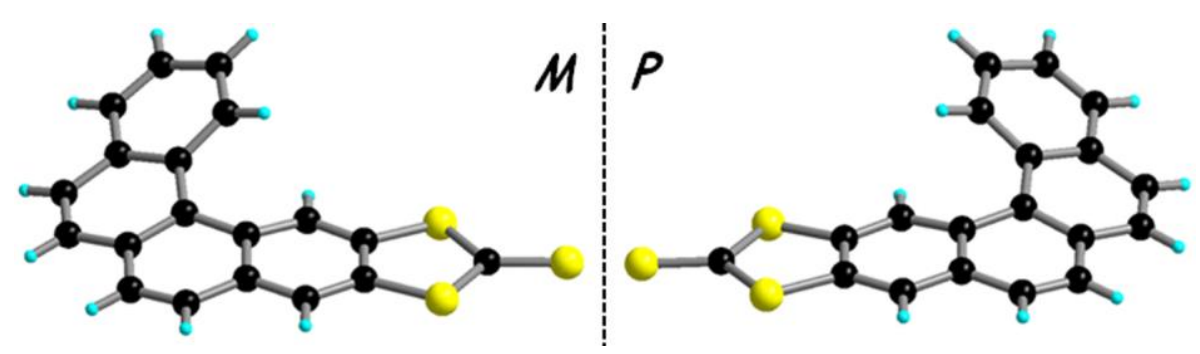

Figure 1. Molecular structures of enantiomeric $(M)-\mathbf{5 a}($ left) and $(P)-\mathbf{5 a}$ (right).

The hc amounts to $26.6^{\circ}$, a typical value for [4] helicenes, while bond lengths and angles are in the usual range. ${ }^{[22]}$ The packing of the molecules is governed by $\pi-\pi$ interactions established between the aromatic rings and also the dithiolethione cycles, leading to the 
formation of stacks which interact laterally by short $\mathrm{S} \cdots \mathrm{S}$ contacts. Although we have been able to resolve 5a in the solid state through the formation of the conglomerate consisting of equal amounts of $(M)$ and $(P)$ enantiomers, as indicated by the absence of any CD signal in the solid state, the low racemisation barrier does not allow resolution of [4] helicenes ${ }^{[25]}$ in solution by HPLC.

The "half"-TTFs 5a-b were then engaged in the classical phosphite mediated hetero-coupling reaction in the presence of ethylenedithio-dithiolone to afford the first examples of TTFhelicenes, 6a-b, isolated as yellow solids in their racemic form. Single crystals of the TTF[4]helicene 6a have been obtained by slow diffusion of pentane onto a solution of compound in THF. At the difference with the precursor 5a, for which the crystallization as conglomerate is probably triggered by the establishment of homochiral $\pi-\pi$ intermolecular interactions between the helicene units, 6a crystallizes as racemate in the centrosymmetric space group $P 2_{1} / n$, monoclinic system, with one independent molecule in the unit cell (Figure 2).

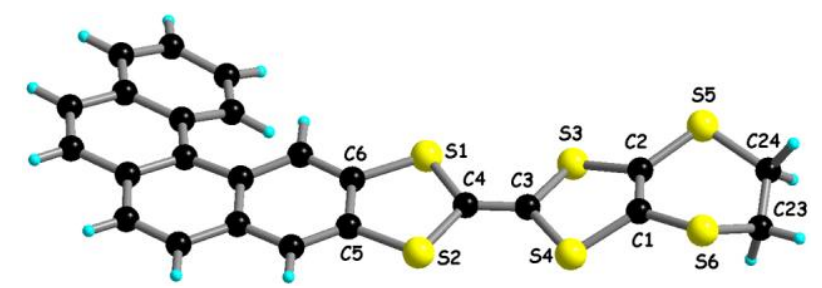

Figure 2. Molecular structure of EDT-TTF-[4]helicene 6a. Only the $(P)$ enantiomer shown here.

The TTF unit is folded along the S3 $\cdots \mathrm{S} 4$ hinge by $21.8^{\circ}$, the central $\mathrm{C} 3=\mathrm{C} 4$ bond amounts to 1.343(3) A, both parameters being characteristic for neutral TTF units, while the he has a value of $22.7^{\circ}$, slightly lower than the one of the precursor 5a. At the supramolecular level there is formation of homochiral stacks, along the $b$ direction, with molecules interacting through $\pi-\pi$ and $\mathrm{S} \cdots \mathrm{S}$ interactions, while in the perpendicular direction $a,(M)$ and $(P)$ enantiomers alternate and interact through $\mathrm{S} \cdots \mathrm{S}$ contacts of $3.71 \AA^{\left[{ }^{[22]}\right.}$ Once again, the low racemisation barrier in $\mathbf{6 a}$ did not allow its chiral resolution. On the contrary, separation of $\mathbf{6 b}$ into its $(M)$ and $(P)$ enantiomers has been successfully achieved by HPLC over a chiral stationary phase (ee higher than $99 \%) .{ }^{[22]}$ They show intense optical activity according to the values of the specific and molar optical rotations $\left([\alpha]_{\mathrm{D}}^{25}=+2188 \pm 1 \%,[\phi]_{\mathrm{D}}^{25}=+13013 \pm 1 \%\right.$ ${ }^{\circ} \mathrm{cm}^{2} / \mathrm{dmol}$ for $(P)-\mathbf{6 b}$ which is the first eluted enantiomer), in the same order of magnitude as the carbo[6]helicene $\left([\phi]_{\mathrm{D}}^{25}=+11950\right) .{ }^{[5 \mathrm{~d}]}$ The solid state structure of the enantiomer $(M)$, for which suitable single crystals were grown by slow diffusion of pentane onto a solution of $(M)$ - 
6b in THF: $\mathrm{CH}_{2} \mathrm{Cl}_{2}$ 1:1, could be determined by $\mathrm{X}$-ray diffraction analysis. The compound crystallizes in the monoclinic non-centrosymmetric space group $C 2$ with one independent molecule of donor and half a molecule of THF in the asymmetric unit. The donor moiety is folded along both internal S $\cdots \mathrm{S}$ hinges by $20.2^{\circ}(\mathrm{S} 2 \cdots \mathrm{S} 4)$ and $23.5^{\circ}(\mathrm{S} 1 \cdots \mathrm{S} 3)$, as often encountered in the case of neutral TTFs, while the he value amounts to $50.7^{\circ}$ (Figure 3 )..$^{[2]}$
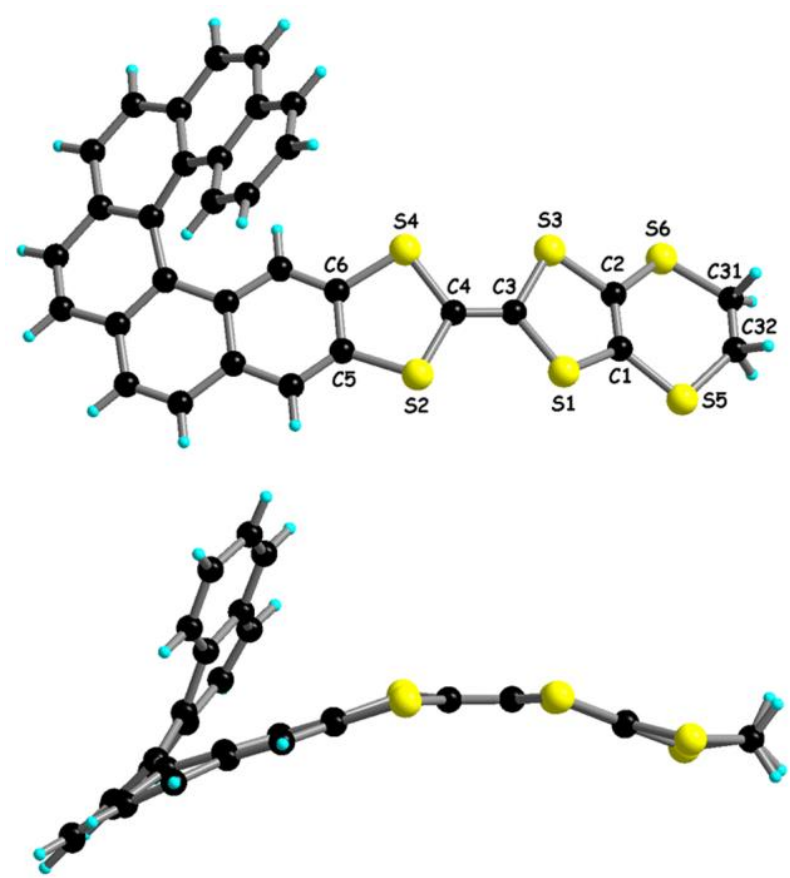

Figure 3. Molecular structure of (M)-EDT-TTF-[6]helicene $6 \mathbf{b}$ (top) along with a side view (bottom).

At the supramolecular level the molecules form chains stabilized by short S $\cdots S$ lateral contacts $(3.47-3.60 \AA$, Figure 4$)$ and $\pi-\pi$ interactions between the aromatic helical units (3.47 - $3.68 \AA$ ) along $b$, and these chains further interact along $c$ through $\pi-\pi$ interactions between the helicenic units $(3.40-3.62 \AA)$ and also S $\cdots S$ van der Waals interactions $(3.74$ $\AA$ ). Moreover, somewhat weaker $\pi-\pi$ interactions (3.62 $\AA$ ) are disclosed along the $a$ direction, thus leading to an overall 3D network with channels running along $b$ containing the crystallization THF molecules. ${ }^{[22]}$ It is thus clear that the packing of TTF[n]helicenes results from the interplay between $S \cdots S$ and helical $\pi-\pi$ interactions, and thus this feature should very likely occur in the solid state structures of radical cation species too, leading, in the field of TTF based crystalline conductors, to unprecedented architectures in which the helical chirality is expressed in the packing. 


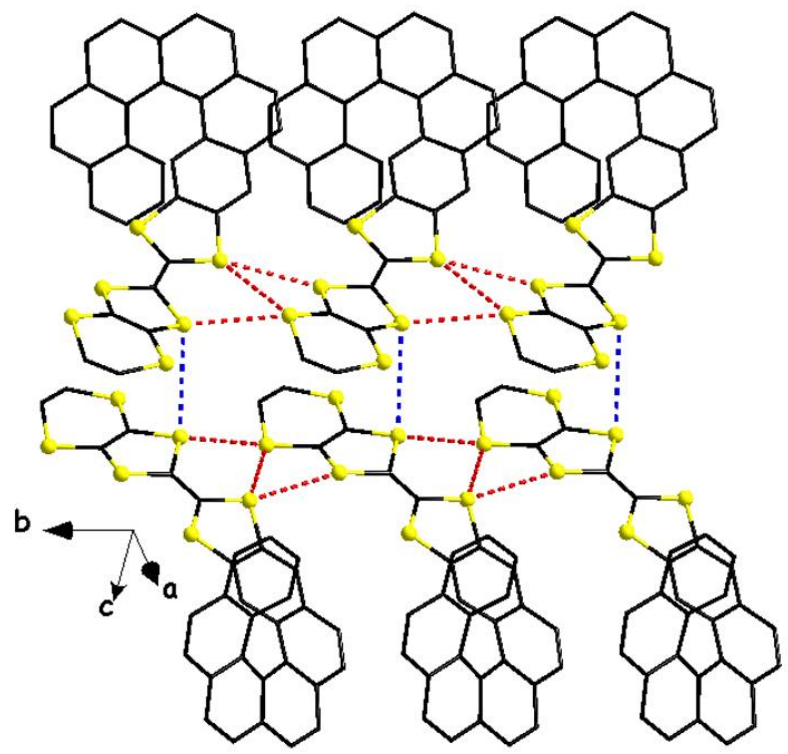

Figure 4. Packing diagram for $(M)-\mathbf{6 b}$. Short $\mathrm{S} \cdots \mathrm{S}$ contacts highlighted in red (along $b$ ) and blue (along $c$ ). The helicenic units establish $\pi-\pi$ interactions along $b$.

Cyclic voltammetry measurements on 6a-b show that they both are convenient precursors for the generation of stable radical cation salts, as suggested by the reversibility of the oxidation processes, ${ }^{[22]}$ while the oxidation potentials are in the normal range for EDT-TTF donors $\left(\mathrm{E}_{1 / 2}^{1}\right.$ of 0.54 and $0.68 \mathrm{~V}$ vs.SCE and $\mathrm{E}_{1 / 2}^{2}$ of 0.98 and $1.13 \mathrm{~V}$ vs. SCE for $\mathbf{6 a}$ and $\mathbf{6 b}$, respectively).

UV-vis and CD spectroscopy: UV-visible spectra of both $\mathbf{6 a}$ and $\mathbf{6 b}$ show intense absorption bands between 250 and $370 \mathrm{~nm}$, with the most intense one peaking at $270-275 \mathrm{~nm}(\varepsilon \approx$ $4.7 \times 10^{4} \mathrm{M}^{-1} \mathrm{~cm}^{-1}$ ), due to $\pi-\pi^{*}$ transitions of the helicenic unit with contributions from TTF based transitions (Figure 4). At lower energy there is an additional band centred at $412 \mathrm{~nm}$ for $\mathbf{6 a}$ and $436 \mathrm{~nm}$ for $\mathbf{6 b}$, with extinction coefficients $\varepsilon$ of the order of $5.7 \times 10^{3}(\mathbf{6 a})$ and $4.5 \times 10^{3}$ (6b) $\mathrm{M}^{-1} \mathrm{~cm}^{-1}$, which may be ascribed to an intramolecular charge transfer (ICT) from TTF to helicene. Circular dichroism spectra have been measured for $\mathbf{6 b}$ enantiomers which show perfect mirror-image relationship (Figure 5), with a first positive band peaking at $333 \mathrm{~nm}$ and a second negative band at $260 \mathrm{~nm}$ for the $(P)$ enantiomer (opposite signs for the $(M)$ enantiomer), in agreement with the classical bisignated signal of [6]helicenes. ${ }^{[3 a, 5]}$ Interestingly, the band at $436 \mathrm{~nm}$, hypothesized as charge transfer from TTF to helicene, is CD active. 

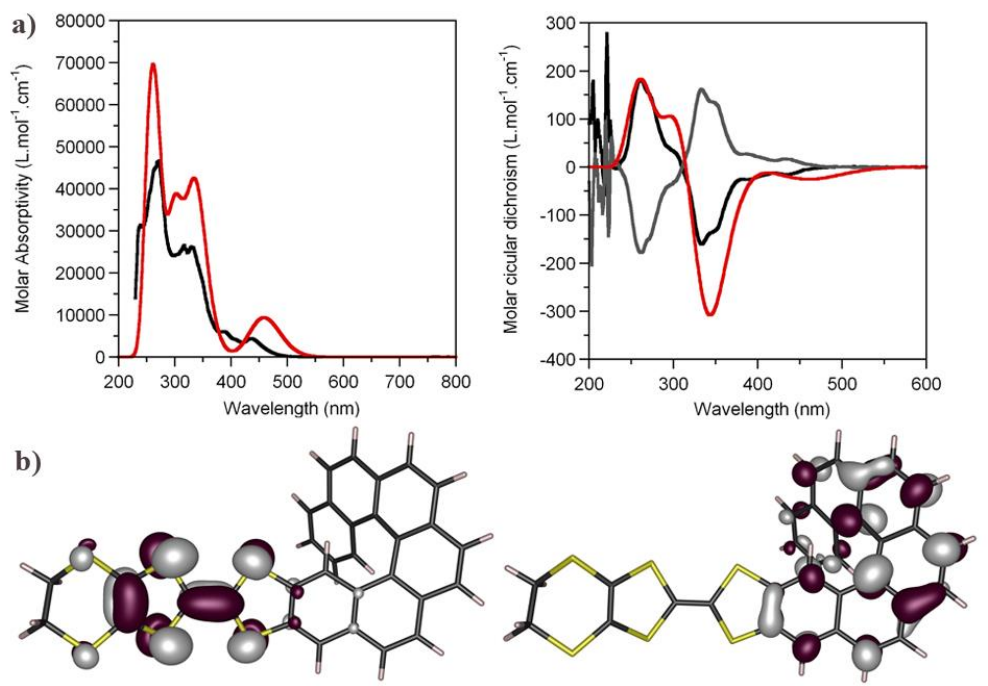

Figure 5. a) Theoretical (red line) and experimental in solution (black line, $5 \times 10^{-5} \mathrm{M}$ in $\mathrm{CH}_{2} \mathrm{Cl}_{2}$ ) absorption spectra of $(M)-6 \mathbf{b}$ (left) and theoretical (red line for $(M)-6 \mathbf{b})$ and experimental in solution (black line for $(M)$ and grey line for $(P)-6 \mathbf{b}, 5 \times 10^{-5} \mathrm{M}$ in $\mathrm{CH}_{2} \mathrm{Cl}_{2}$ ) $\mathrm{CD}$ spectra (right); b) HOMO (left) and LUMO (right) of (M)-6b (6$31+\mathrm{G}(2 \mathrm{~d}, 2 \mathrm{p})$, isovalue of 0.05$)$.

In order to assign and characterize the nature of the electronic transitions appearing in the UV-vis and CD spectra, theoretical calculations at the TD DFT/PBE0 level have been performed on the optimized geometry of $(M)-6 \mathbf{b}$, which proves to be in excellent agreement with the X-ray structure. ${ }^{[22]}$ A first interesting observation concerns the composition of the frontier orbitals, as the HOMO ( $\pi$ type) is based at $92 \%$ on the EDT-TTF part, while the LUMO ( $\pi^{*}$ type) spans the helicene unit at $92 \%$ (Figure 5). It is therefore likely that an ICT might occur, corresponding to a HOMO $\rightarrow$ LUMO excitation. Indeed, the calculated singlet electronic excitations show that the less energetic transition measured at $459 \mathrm{~nm}\left(21767 \mathrm{~cm}^{-1}\right.$, $f=0.125$ ) describes the ICT from TTF to helicene and, moreover, it is CD active and negative $\left(\mathrm{R}=-122 \times 10^{-40} \mathrm{esu}^{2} \mathrm{~cm}^{2}\right)$, in agreement with the experimental UV-vis and CD spectra. The typical bisignated helicenic CD signal is also very well reproduced by the calculations, with the negative to positive crossing point perfectly matching the experimental CD curve, and, indeed, the corresponding transitions are mainly $\pi-\pi^{*}$ helicene based, with, however, some variable contributions from the TTF unit. ${ }^{[22]}$ Most interestingly, upon oxidation of the TTF unit with one equiv. of $\mathrm{NOSbF}_{6}$ the ICT band at $436 \mathrm{~nm}$ completely vanishes, while the intense bands due to helicene based transitions are slightly red-shifted (Figure 6). Notably, the oxidized species show in the NIR region a large band spanning between $\sim 1080-\sim 720 \mathrm{~nm}$, very likely arising from the addition of HOMO-1/HOMO-2 $\rightarrow$ SOMO transitions, ${ }^{[26]}$ that can be regarded as reverse ICT from helicene (in the composition of the quasi-degenerated 
HOMO-1 and HOMO-2 the helicene unit is largely dominant ${ }^{[22]}$ to TTF. In order to check this assumption TD DFT calculations have been performed on the radical cation $[(M)-\mathbf{6 b}]^{+\cdot}$ with the PBE0 functional. ${ }^{[22]}$ As hypothesized, the lowest energy transitions, amongst which the most intense one at $1344 \mathrm{~nm}$ is negative in sign, are due to reverse ICT excitations from helicene to TTF. It is thus clear that the presence of the electroactive TTF unit fused to the helicene skeleton allows for the redox modulation of the chiroptical properties of the resulting assembly. Remarkably, the system is perfectly reversible over several cycles of electrochemical oxidation-reduction processes (Figure 6), as illustrated for example by the variation of the $\mathrm{CD}$ spectrum at $306 \mathrm{~nm}$, thus providing one of the very rare examples of helicene based electrochemical chiroptical switch. ${ }^{13}$

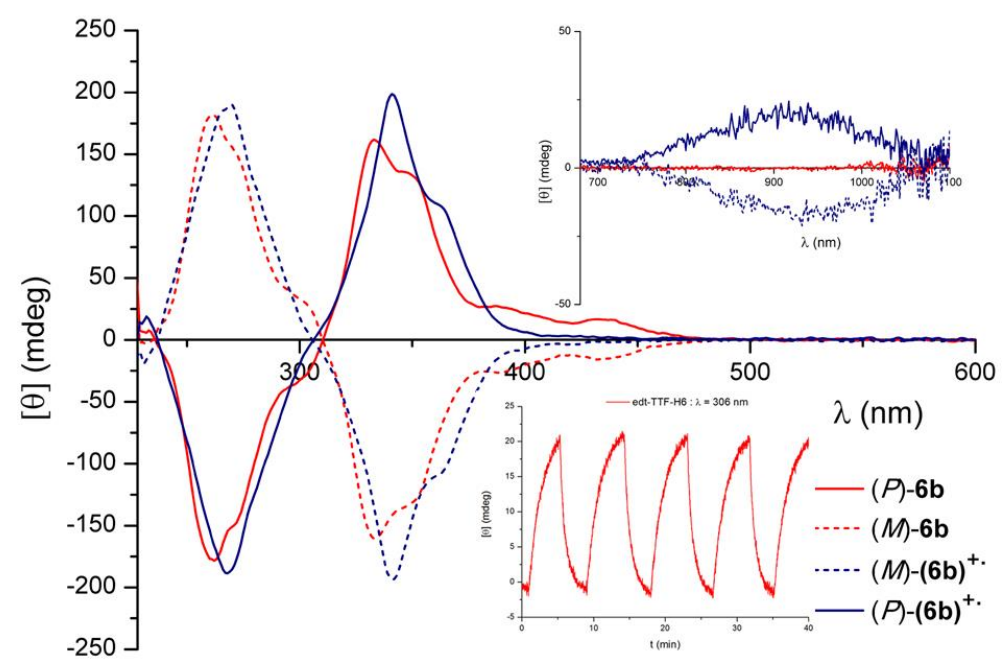

Figure 6. CD spectra of $(P)-(+) /(M)-(-)$ enantiomers of $\mathbf{6} \mathbf{b}$ and of their one-electron chemically oxidized species in DCM $\left(5 \times 10^{-5} \mathrm{M}\right)$ at room temperature; insets: NIR-CD region spectra (DCM, $\left.5 \times 10^{-4} \mathrm{M}\right)$ (up) and redox chiroptical switching observed by $\mathrm{CD}$ at $306 \mathrm{~nm}$ for $(M)-6 \mathbf{b}$ (bottom).

\section{Conclusions}

In summary, the first tetrathiafulvalene-helicene, with a fused connection between the two units, have been designed, synthesized, isolated as pure enantiomers in the case of the [6]helicenes, and characterized, including by single crystal X-ray analyses. Key synthetic intermediates are protected helicene-dithiolates which present a great potential as precursors for helical metal-dithiolene complexes. This family of inherently helical TTFs opens the way towards the preparation of conducting radical cation salts with helical packings in the solid state, as a most promising perspective in the field of chiral conductors. The excellent chiroptical properties of the helicene skeleton are preserved in TTF-helicenes and they show 
redox modulation thanks to the conjugation between the two units. Variation of the TTF and helicene units, as well as the connectivity between them, together with the preparation of crystalline radical cation salts are under study. In particular the investigation of the dynamic chirality of the [4]helicene derivatives through the synthesis of [4]helicene-TTF-[4]helicene or TTF-[4]helicene derivatives containing additional TTF appended chiral groups as strategies to induce more intense redox modulation of the chiroptical signal is envisaged.

\section{Experimental Section}

General: Dry THF and ether were obtained from a solvent purification system (LC Technology Solutions Incorporated). Nuclear magnetic resonance spectra were recorded on a Bruker Advance DRX 300 spectrometer operating at $300 \mathrm{MHz}$ for ${ }^{1} \mathrm{H}$ and $75 \mathrm{MHz}$ for ${ }^{13} \mathrm{C}$. Chemical shifts are expressed in parts per million (ppm) downfield from external TMS. The following abbreviations are used: $s$, singlet; $d$, doublet; $t$, triplet; $m$, multiplet. MALDI-TOF MS spectra were recorded on a Bruker Biflex-IIITM apparatus, equipped with a $337 \mathrm{~nm} \mathrm{N_{2 }}$ laser. Elemental analyses were recorded using Flash 2000 Fisher Scientific Thermo Electron analyzer. IR spectra were recorded on Bruker FT-IR Vertex 70 spectrometer equipped with a Platinum diamond ATR accessory. UV-Vis spectra were recorded in solution using either a Lambda 19 or a Lambda 250 PERKIN ELMER Spectrometer. Circular dichroism (CD) measurements have been performed with a JASCO Corp. J-715 or J-810 apparatus (IFR140 facility - Université de Rennes 1), adapted with an extended wavelength option to $1100 \mathrm{~nm}$ for NIR-CD.

Synthesis of 2-(3,4-dibromostyryl)naphthalene 2a: To a suspension of phosphonium bromide 1a $(1.3 \mathrm{~g}, 2.69 \mathrm{mmol})$ in dry THF $(30 \mathrm{~mL})$ and cooled to $-78{ }^{\circ} \mathrm{C}$ under argon, was added dropwise n-butyllithium 1.6 $\mathrm{M}$ in hexanes $(1.77 \mathrm{~mL}, 1.05$ eq.) over $5 \mathrm{~min}$, and the resulting orange solution was stirred at $-78^{\circ} \mathrm{C}$ for $10 \mathrm{~min}$, warmed to RT over $30 \mathrm{~min}$ (red solution), then re-cooled to $-78{ }^{\circ} \mathrm{C}$. A solution of 3,4-dibromobenzaldehyde (710 mg, 2.69 $\mathrm{mmol})$ in THF ( $5 \mathrm{~mL}$ ) was then added dropwise, and the resulting pale yellow solution was stirred at $-78{ }^{\circ} \mathrm{C}$ for $10 \mathrm{~min}$, warmed to RT and stirred during 4 hours. The reaction mixture was filtered over celite and concentrated in vacuo. After chromatography over $\mathrm{SiO}_{2}$ (hexane as eluent, $\mathrm{Rf}=0.7)$, $2 \mathbf{a}$ was obtained as a pale yellow oil (cis+trans mixture) (850 $\mathrm{mg}, 82 \%)$. ${ }^{1} \mathrm{H} \mathrm{NMR}\left(\mathrm{CDCl}_{3}, 300 \mathrm{MHz}\right) \delta(\mathrm{ppm}) 7.89-7.80(\mathrm{~m}, 5 \mathrm{H}), 7.78-7.72(\mathrm{~m}, 1.5 \mathrm{H}), 7.63(\mathrm{~d}, J=8.3$ $\mathrm{Hz}, 1 \mathrm{H}), 7.60(\mathrm{~m}, 0.25 \mathrm{H}) 7.56-7.49(\mathrm{~m}, 2.25 \mathrm{H}), 7.44(\mathrm{~d}, J=8.3 \mathrm{~Hz}, 0.25 \mathrm{H}), 7.38-7.32(\mathrm{~m}$, 
$1 \mathrm{H}), 7.30\left(\mathrm{~d}, J=16.3 \mathrm{~Hz}, 1 \mathrm{H}_{\text {trans }}\right), 7.13\left(\mathrm{~d}, J=16.2 \mathrm{~Hz}, 1 \mathrm{H}_{\text {trans }}\right), 6.86(\mathrm{~d}, J=12.2 \mathrm{~Hz}$, $\left.0.25 \mathrm{H}_{c i s}\right), 6.56\left(\mathrm{~d}, J=12.2 \mathrm{~Hz}, 0.25 \mathrm{H}_{\text {cis }}\right) ;\left\{{ }^{1} \mathrm{H}\right\}^{13} \mathrm{C} \mathrm{NMR}\left(\mathrm{CDCl}_{3}, 75 \mathrm{MHz}\right) \delta(\mathrm{ppm}) 138.3$, 134.0, 133.8, 133.7, 133.3, 131.4, 130.8, 129.0, 128.5, 128.2, 127.8, 127.3, 130.0, 126.6, 126.4, 126.3, 125.2, 123.3; MS (MALDI-TOF) $\mathrm{m} / \mathrm{z}=487.96\left(\mathrm{M}^{+}\right)$; Anal. Calc. for $\mathrm{C}_{18} \mathrm{H}_{12} \mathrm{Br}_{2}$ : C, 55.71; H, 3.12. Found: C, 55.78; H, 3.09\%.

Synthesis of 1,2-dibromo-5-(2-(benzo[c]phenanthr-2-yl)vinyl)benzene $2 \mathrm{~b}:$ To a suspension of phosphonium bromide $\mathbf{1 b}(600 \mathrm{mg}, 1.03 \mathrm{mmol})$ in dry THF (30 mL) cooled to $78{ }^{\circ} \mathrm{C}$ under argon, was added dropwise n-butyllithium 1.6M in hexanes (675 $\mu \mathrm{L}, 1$ eq.) over $5 \mathrm{~min}$, and the resulting orange solution was stirred at $-78{ }^{\circ} \mathrm{C}$ for $10 \mathrm{~min}$, warmed to RT over $30 \mathrm{~min}$ (red solution), then re-cooled to $-78{ }^{\circ} \mathrm{C}$. A solution of 3,4-dibromobenzaldehyde (272 $\mathrm{mg}, 1.03 \mathrm{mmol})$ in THF ( $5 \mathrm{~mL})$ was then added dropwise, and the resulting pale yellow solution was stirred at $-78{ }^{\circ} \mathrm{C}$ for $10 \mathrm{~min}$, warmed to RT and stirred further during 4 hours. The reaction mixture was filtered over celite and concentrated in vacuo. After chromatography over $\mathrm{SiO}_{2}$ (hexane as eluent, $\mathrm{Rf}=0.5$ ), $\mathbf{2 b}$ was obtained as a pale yellow oil (cis+trans mixture) (376 mg, 75\%). ${ }^{1} \mathrm{H} \mathrm{NMR}\left(\mathrm{CD}_{2} \mathrm{Cl}_{2}, 300 \mathrm{MHz}\right) \delta(\mathrm{ppm}) 9.15(\mathrm{~d}, J=8.3 \mathrm{~Hz}$, $0.5 \mathrm{H}), 9.04(\mathrm{~s}, 0.5 \mathrm{H}), 8.95(\mathrm{~s}, 1 \mathrm{H}), 8.52(\mathrm{~d}, J=8.5 \mathrm{~Hz}, 1 \mathrm{H}), 8.11-8.02(\mathrm{~m}, 1.6 \mathrm{H}), 7.96-7.81$ (m, 7.5H), 7.80-7.64 (m, 5H), 7.56-7.45 (m, 4H), $7.27\left(\mathrm{~d}, J=15.1 \mathrm{~Hz}, 0.5 \mathrm{H}_{\text {trans }}\right), 7.22-7.16$ (t, $J=7.5 \mathrm{~Hz}, 2 \mathrm{H}), 6.97\left(\mathrm{~d}, J=16.2 \mathrm{~Hz}, 0.5 \mathrm{H}_{\text {trans }}\right), 6.89\left(\mathrm{~d}, J=12.1 \mathrm{~Hz}, 1 \mathrm{H}_{\text {cis }}\right), 6.56(\mathrm{~d}, J=12.1$ $\left.\mathrm{Hz}, 1 \mathrm{H}_{c i s}\right) ;\left\{{ }^{1} \mathrm{H}\right\}{ }^{13} \mathrm{C} \mathrm{NMR}\left(\mathrm{CDCl}_{3}, 300 \mathrm{MHz}\right) \delta(\mathrm{ppm}) 138.3,134.3,133.7,133.6,133.4$, $132.8,131.4,131.3,131.2$, 130.6, 130.3, 129.1, 128.7, 127.8, 127.7, 127.4, 127.3, 127.1, $126.9,126.43,126.38,126.31,126.0,125.2,123.3,123.0 ;$ HRMS (electrospray) $\mathrm{m} / \mathrm{z}=485.96$ $\left(\mathrm{M}^{+}\right)$.

Synthesis of 2,3-dibromobenzo[c]phenanthrene 3a: 2-(3,4-dibromostyryl)naphthalene 2a (cis+trans mixture) $(700 \mathrm{mg}, 1.80 \mathrm{mmol})$ and iodine (catalytic amount) were dissolved in toluene $(700 \mathrm{~mL})$ and placed in a photoreactor equipped with an immersion lamp (150W). The mixture was irradiated for one night. After evaporation of the solvent and purification by chromatography over $\mathrm{SiO}_{2}$ (pentane as eluent, $\mathrm{Rf}=0.7$ ), 3a was obtained as a pale yellow oil (550 mg, 79\%). ${ }^{1} \mathrm{H} \mathrm{NMR}\left(\mathrm{CDCl}_{3}, 300 \mathrm{MHz}\right) \delta(\mathrm{ppm}) 9.38(\mathrm{~s}, 1 \mathrm{H}), 8.97$ (d, $\left.J=8.2 \mathrm{~Hz}, 1 \mathrm{H}\right)$, $8.27(\mathrm{~s}, 1 \mathrm{H}), 8.06-8.00(\mathrm{~m}, 2 \mathrm{H}), 7.96-7.91(\mathrm{~m}, 2 \mathrm{H}), 7.90-7.65(\mathrm{~m}, 9 \mathrm{H}) ;\left\{{ }^{1} \mathrm{H}\right\}{ }^{13} \mathrm{C} \mathrm{NMR}$ $\left(\mathrm{CDCl}_{3}, 75 \mathrm{MHz}\right) \delta(\mathrm{ppm}) 133.6,133.5,133.3,132.5,132.4,131.9,131.5,131.41,131.38$, 130.2 , 130.1, 130.0, 129.8, 129.0, 128.8, 128.7, 128.5, 128.4, 128.2, 127.4, 127.1, 127.0, $126.9,126.71,126.67,126.60,126.4,126.2,126.0,125.8,122.4,121.8,120.6$; MS (MALDITOF) $\mathrm{m} / \mathrm{z}=385.9\left(\mathrm{M}^{+}\right)$. 
Synthesis of 2,3-dibromo[6]helicene 3b: 1,2-dibromo-5-(2-(benzo[c]phenanthr-2yl)vinyl)benzene $\mathbf{2 b}$ (cis+trans mixture) (500 $\mathrm{mg}, 1.02 \mathrm{mmol})$ and iodine (catalytic amount) were dissolved in toluene $(700 \mathrm{~mL})$ and placed in a photoreactor equipped with an immersion lamp (150W). The mixture was irradiated for one night. After evaporation of the solvent and purification by chromatography over $\mathrm{SiO}_{2}$ (pentane as eluent, $\mathrm{Rf}=0.6$ ), $\mathbf{3 b}$ was obtained as a white solid (308 mg, 62\%). Suitable single crystals for X-ray analysis have been obtained by recrystallization in $\mathrm{CH}_{2} \mathrm{Cl}_{2}$ /hexane (2:1). ${ }^{1} \mathrm{H} \mathrm{NMR}\left(\mathrm{CDCl}_{3}, 300 \mathrm{MHz}\right) \delta(\mathrm{ppm})$ 8.11-7.96 (m, $8 \mathrm{H}), 7.94-7.90(\mathrm{~m}, 2 \mathrm{H}), 7.81(\mathrm{~d}, J=8.6 \mathrm{~Hz}, 1 \mathrm{H}), 7.56(\mathrm{~d}, J=8.5 \mathrm{~Hz}, 1 \mathrm{H}), 7.38(\mathrm{t}, J=7.5 \mathrm{~Hz}$, $1 \mathrm{H}), 6.82(\mathrm{t}, J=7.8 \mathrm{~Hz}, 1 \mathrm{H}) ;\left\{{ }^{1} \mathrm{H}\right\}{ }^{13} \mathrm{C} \mathrm{NMR}\left(\mathrm{CDCl}_{3}, 300 \mathrm{MHz}\right) \delta(\mathrm{ppm}) 133.3,132.8,132.3$, 131.7 , 131.6, 131.5, 129.7, 129.3, 128.3, 128.0, 127.95, 127.9, 127.8, 127.3, 127.1, 127.0, 126.6, 126.2, 125.0, 123.7, 121.2, 120.9; MS (MALDI-TOF) $\mathrm{m} / \mathrm{z}=485.50\left(\mathrm{M}^{+}\right)$; Anal. Calc. for $\mathrm{C}_{26} \mathrm{H}_{14} \mathrm{Br}_{2}$ : C, 64.23; H, 2.90. Found: C, 64.02; H, 2.92\%.

Synthesis of 2,3-bis(2'-cyanoethylsulfanyl)-(benzo[c]phenanthrene 4a: 2,3dibromobenzo[c]phenanthrene 3a (500 mg, $1.30 \mathrm{mmol}), \mathrm{Pd}\left(\mathrm{PPh}_{3}\right)_{4}(150 \mathrm{mg}, 10 \% \mathrm{~mol})$ and 3(tributylstannylsulfanyl)propanenitrile $(1.17 \mathrm{~g}, 3.11 \mathrm{mmol})$ were placed in a Schlenk tube and dissolved in dry toluene $(20 \mathrm{~mL})$. The reaction mixture was stirred during 2 days under argon at $110{ }^{\circ} \mathrm{C}$. After evaporation of solvent and purification by chromatography over $\mathrm{SiO}_{2}$ $\left(\mathrm{CH}_{2} \mathrm{Cl}_{2}\right.$ as eluent, $\left.\mathrm{Rf}=0.2\right), \mathbf{4 a}$ was obtained as a white solid $(377 \mathrm{mg}, 73 \%) .{ }^{1} \mathrm{H} \mathrm{NMR}$ $\left(\mathrm{CDCl}_{3}, 300 \mathrm{MHz}\right) \delta(\mathrm{ppm}) 99.24(\mathrm{~s}, 1 \mathrm{H}), 9.00(\mathrm{~d}, J=8.5 \mathrm{~Hz}, 1 \mathrm{H}), 8.09(\mathrm{~d}, J=7.9 \mathrm{~Hz}, 1 \mathrm{H})$, 8.01-7.78 (m, 6H), $7.71(\mathrm{t}, J=7.5 \mathrm{~Hz}, 1 \mathrm{H}), 3.42-3.38(\mathrm{t}, J=7.3 \mathrm{~Hz}, 2 \mathrm{H}), 3.37-3.32(\mathrm{t}, J=7.3$ $\mathrm{Hz}, 2 \mathrm{H}), 2.84-2.79(\mathrm{t}, J=7.3 \mathrm{~Hz}, 2 \mathrm{H}), 2.76-2.71(\mathrm{t}, J=7.3 \mathrm{~Hz}, 2 \mathrm{H}) ;\left\{{ }^{1} \mathrm{H}\right\}{ }^{13} \mathrm{C} \mathrm{NMR}\left(\mathrm{CDCl}_{3}\right.$, $75 \mathrm{MHz}) \delta(\mathrm{ppm}) 133.7,133.4,133.3,132.4,131.9,131.5,130.2,129.8,129.5,128.9,128.7$, $128.4,127.2,126.9,126.7,126.6,126.5,126.2,117.9,117.8,30.0,29.2,18.1,18.0$; MS (MALDI-TOF) $\mathrm{m} / \mathrm{z}=397.9\left(\mathrm{M}^{+}\right)$; Anal. Calc. for $\mathrm{C}_{24} \mathrm{H}_{18} \mathrm{~N}_{2} \mathrm{~S}_{2}$ : C, 72.33; H, 4.55; N, 7.03; S, 16.09. Found: C, 72.73; H, 4.43; N, 6.96; S, $15.90 \%$.

Synthesis of 2,3-bis(2'-cyanoethylsulfanyl)[6]helicene 4b: 1,2-dibromo[6]helicene 3a (400 $\mathrm{mg}, 0.82 \mathrm{mmol}), \mathrm{Pd}\left(\mathrm{PPh}_{3}\right)_{4}(95 \mathrm{mg}, 10 \mathrm{~mol} \%)$ and 3-(tributylstannylsulfanyl)propanenitrile (743 mg, $1.98 \mathrm{mmol})$ were placed in a Schlenk tube and dissolved in dry toluene $(20 \mathrm{~mL})$. The reaction mixture was stirred during 2 days under argon at $110{ }^{\circ} \mathrm{C}$. After evaporation of solvent and purification by chromatography over $\mathrm{SiO}_{2}\left(\mathrm{CH}_{2} \mathrm{Cl}_{2}\right.$ as eluent, $\left.\mathrm{Rf}=0.2\right), \mathbf{4 b}$ was obtained as a white solid (262 mg, 64\%). ${ }^{1} \mathrm{H}$ NMR $\left(\mathrm{CDCl}_{3}, 300 \mathrm{MHz}\right) \delta(\mathrm{ppm})$ 8.08-7.99 (m, $7 \mathrm{H}), 7.96(\mathrm{~d}, J=8.0 \mathrm{~Hz}, 1 \mathrm{H}), 7.93-7.85(\mathrm{~m}, 2 \mathrm{H}), 7.65-7.62(\mathrm{~m}, 2 \mathrm{H}), 7.38(\mathrm{t}, J=7.5 \mathrm{~Hz}, 1 \mathrm{H})$, $6.81(\mathrm{t}, J=7.7 \mathrm{~Hz}, 1 \mathrm{H}), 3.23-3.07(\mathrm{~m}, 2 \mathrm{H}), 2.65-2.49(\mathrm{~m}, 2 \mathrm{H}), 2.36-2.12(\mathrm{~m}, 4 \mathrm{H}) ;\left\{{ }^{1} \mathrm{H}\right\}{ }^{13} \mathrm{C}$ $\mathrm{NMR}\left(\mathrm{CDCl}_{3}, 300 \mathrm{MHz}\right) \delta(\mathrm{ppm})$ 133.6, 133.5, 132.2, 131.8, 131.7, 131.6, 130.8, 130.7, 
$129.9,129.5,129.2,128.1,128.0,127.9,127.8,127.7,127.6,127.5,127.3,127.2,127.0$, $126.8,126.7,126.2,125.0,123.7,118.0,117.8,29.6,29.0,17.7,17.5$. MS (MALDI-TOF) $\mathrm{m} / \mathrm{z}=497.9\left(\mathrm{M}^{+}\right)$; Anal. Calc. for $\mathrm{C}_{32} \mathrm{H}_{22} \mathrm{~N}_{2} \mathrm{~S}_{2}$ : C, 77.07; H, 4.45; N, 5.62; S, 12.86. Found: C, 77.35; H, 4.38; N, 5.52; S, 12.36\%.

Synthesis of 2,3-dithiolethione-benzo[c]phenanthrene 5a: 2,3-bis(2'-cyanoethylsulfanyl)(benzo[c]phenanthrene 4a $(300 \mathrm{mg}, 0.75 \mathrm{mmol}$ ) was placed in a Schlenk tube and then dissolved in dry THF $(10 \mathrm{~mL})$. Tetrabutylammonium hydroxide $(1 \mathrm{M}$ in solution with methanol) was added $(1.57 \mathrm{~mL}, 1.57 \mathrm{mmol})$ and the resulting solution was stirred $1 \mathrm{~h}$ and it gradually became orange-red. Thiophosgene $(58 \mu \mathrm{L}, 0.75 \mathrm{mmol})$ was then added to the solution and the resulting yellow reaction mixture was stirred for $2 \mathrm{~h}$. After evaporation of solvent through vacuum ramp and purification by chromatography over $\mathrm{SiO}_{2}$ (hexane $/ \mathrm{CH}_{2} \mathrm{Cl}_{2}$ $1: 1$ as eluent, $\mathrm{Rf}=0.5)$, 5a was isolated as a yellow solid $(191 \mathrm{mg}, 76 \%)$. Suitable single crystals for X-ray analysis have been obtained by recrystallization in toluene.

${ }^{1} \mathrm{H}$ NMR $\left(\mathrm{CD}_{2} \mathrm{Cl}_{2}, 300 \mathrm{MHz}\right) \delta(\mathrm{ppm}) 9.20(\mathrm{~s}, 1 \mathrm{H}), 9.00(\mathrm{~d}, J=8.5 \mathrm{~Hz}, 1 \mathrm{H}), 8.12-8.08$ (m, 2H), $7.98(\mathrm{~d}, J=8.6 \mathrm{~Hz}, 1 \mathrm{H}), 7.93-7.85(\mathrm{~m}, 3 \mathrm{H}), 7.81-7.76(\mathrm{t}, J=7.6 \mathrm{~Hz}, 1 \mathrm{H}), 7.73-7.69(\mathrm{~m}$, $1 \mathrm{H}) ;\left\{{ }^{1} \mathrm{H}\right\}{ }^{13} \mathrm{C} \mathrm{NMR}\left(\mathrm{CDCl}_{3}, 75 \mathrm{MHz}\right) \delta(\mathrm{ppm}) 212.8,139.7,138.8,133.7,132.3,131.4$, 129.9 , 129.2, 128.9, 128.6, 128.4, 127.1, 127.0, 126.7, 126.5, 126.4, 120.5, 120.1; MS (MALDI-TOF) $\mathrm{m} / \mathrm{z}=334.5\left(\mathrm{M}^{+}\right)$; Anal. Calc. for $\mathrm{C}_{19} \mathrm{H}_{10} \mathrm{~S}_{3}$ : C, 68.23; H, 3.01; S, 28.76 found: C, 68.04; H, 2.99; S, 28.33\%.

Synthesis of 2,3-dithiolethione[6]helicene 5b: 2,3-bis(2'-cyanoethylsulfanyl)[6]helicene $4 \mathbf{b}$ (200 mg, $0.4 \mathrm{mmol}$ ) was placed in a Schlenk tube and dissolved in dry THF (10 mL). Tetrabutylammonium hydroxide ( $1 \mathrm{M}$ in solution with methanol) was added ( $834 \mu \mathrm{L}, 0.83$ mmol) and the resulting solution was stirred for $1 \mathrm{~h}$ during which it became orange-red. Thiophosgene was then added to the solution $(31 \mu \mathrm{L}, 0.4 \mathrm{mmol})$ and the resulting yellow reaction mixture was stirred for $2 \mathrm{~h}$. After evaporation of solvent through vacuum line and purification by chromatography over $\mathrm{SiO}_{2}\left(\mathrm{CH}_{2} \mathrm{Cl}_{2}\right.$ as eluent, $\left.\mathrm{Rf}=0.6\right) \mathbf{5 b}$ was obtained as a yellow solid (116 mg, 67\%). ${ }^{1} \mathrm{H}$ NMR $\left(\mathrm{CD}_{2} \mathrm{Cl}_{2}, 300 \mathrm{MHz}\right) \delta(\mathrm{ppm})$ 8.15-8.00 (m, 7H), 7.95$7.90(\mathrm{~m}, 3 \mathrm{H}), 7.65(\mathrm{~s}, 1 \mathrm{H}), 7.54(\mathrm{~d}, J=8.5 \mathrm{~Hz}, 1 \mathrm{H}), 7.33(\mathrm{t}, J=7.5 \mathrm{~Hz}, 1 \mathrm{H}), 6.76(\mathrm{t}, J=7.7$ $\mathrm{Hz}, 1 \mathrm{H}) ;\left\{{ }^{1} \mathrm{H}\right\}{ }^{13} \mathrm{C} \mathrm{NMR}\left(\mathrm{CDCl}_{3}, 300 \mathrm{MHz}\right) \delta$ (ppm) 213.4, 138.1, 138.0, 133.4, 132.1, 131.8, $131.6,130.7$, 129.1, 128.6, 128.2, 128.0, 127.9, 127.8, 127.7, 127.2, 127.1, 127.0, 126.8, 126.7, 126.3, 126.1, 124.9, 123.6, 120.2, 119.7; MS (MALDI-TOF) m/z = $434.7\left(\mathrm{M}^{+}\right)$; Anal. Calc. for $\mathrm{C}_{27} \mathrm{H}_{14} \mathrm{~S}_{3}$ : C, 74.62; H, 3.25; S, 22.13. Found: C, 74.24; H, 3.59; S, $22.01 \%$.

Synthesis of ethylenedithio-tetrathiafulvalene-[4]helicene 6a: 2,3-dithiolethionebenzo[c]phenanthrene $\mathbf{5 a}(100 \mathrm{mg}, 0.30 \mathrm{mmol})$ and an excess of 4,5-ethylenedithio-2-oxo- 
1,3-dithiole (200 mg, $0.96 \mathrm{mmol}$ ) were placed in a Schlenk tube under argon. Dry trimethylphosphite $(10 \mathrm{~mL})$ was then added and the resulting mixture was stirred at $130{ }^{\circ} \mathrm{C}$ for $4 \mathrm{~h}$. After evaporation of the trimethylphosphite via azeotrope co-distillation with toluene (x3), and purification by chromatography over $\mathrm{SiO}_{2}\left(\mathrm{CS}_{2} /\right.$ cyclohexane 1:2 as eluent, $\mathrm{Rf}=$ $0.3)$, 6a was obtained as a yellow solid (86 mg, 58\%). ${ }^{1} \mathrm{H}$ NMR $\left(\mathrm{CDCl}_{3}+C S_{2} 1: 1,300 \mathrm{MHz}\right) \delta$ (ppm) $8.96(\mathrm{~m}, 2 \mathrm{H}), 8.01(\mathrm{~m}, 1 \mathrm{H}), 7.91-7.61(\mathrm{~m}, 7 \mathrm{H}), 3.37(\mathrm{~m}, 4 \mathrm{H}) ;\left\{{ }^{1} \mathrm{H}\right\}{ }^{13} \mathrm{C} \mathrm{NMR}\left(\mathrm{CDCl}_{3}\right.$, $300 \mathrm{MHz}) \delta(\mathrm{ppm}) 135.7,133.7,132.2,131.2,130.1,128.9,128.8,127.8,127.41,127.36$, 126.8, 126.61, 126.58, 126.48, 126.2, 120.6, 119.9, 30.4; MS (MALDI-TOF) $\mathrm{m} / \mathrm{z}=493.8$ $\left(\mathrm{M}^{+}\right)$; Anal. Calc. for $\mathrm{C}_{24} \mathrm{H}_{14} \mathrm{~S}_{6}$ : $\mathrm{C}, 58.26 ; \mathrm{H}, 2.85 ; \mathrm{S}, 38.89$ found: $\mathrm{C}, 57.77 ; \mathrm{H}, 2.80$; $\mathrm{S}$, $38.52 \%$.

Synthesis of ethylenedithio-tetrathiafulvalene-[6]helicene 6b: 2,3-dithiolethione[6]helicene $\mathbf{5 b}(100 \mathrm{mg}, 0.23 \mathrm{mmol})$ and an excess of 4,5-ethylenedithio-2-oxo-1,3-dithiole (150 mg, 0.72 mmol), were placed in a Schlenk tube under argon. Dry trimethylphosphite $(10 \mathrm{~mL})$ was then added and the resulting mixture was stirred at $130{ }^{\circ} \mathrm{C}$ for $4 \mathrm{~h}$. After evaporation of the trimethylphosphite via azeotrope co-distillation with toluene (x3), and purification by chromatography over $\mathrm{SiO}_{2}\left(\mathrm{CS}_{2} /\right.$ cyclohexane 1:2 as eluent, $\left.\mathrm{Rf}=0.2\right)$, $\mathbf{6 b}$ was obtained as a yellow solid (56 mg, 41\%). ${ }^{1} \mathrm{H}$ NMR $\left(\mathrm{CDCl}_{3}+\mathrm{CS}_{2} 1: 1,300 \mathrm{MHz}\right) \delta(\mathrm{ppm})$ 8.04-7.85 (m, 8H), $7.77(\mathrm{~d}, J=8.5 \mathrm{~Hz}, 1 \mathrm{H}), 7.65-7.61(\mathrm{~m}, 2 \mathrm{H}), 7.45(\mathrm{~s}, 1 \mathrm{H}), 7.36(\mathrm{t}, J=7.6 \mathrm{~Hz}, 1 \mathrm{H}), 6.81(\mathrm{t}, J=$ $7.7 \mathrm{~Hz}, 1 \mathrm{H}), 3.32(\mathrm{~s}, 4 \mathrm{H}) ;\left\{{ }^{1} \mathrm{H}\right\}{ }^{13} \mathrm{C} \mathrm{NMR}\left(\mathrm{CDCl}_{3}+\mathrm{CS}_{2} 1: 1,300 \mathrm{MHz}\right) \delta(\mathrm{ppm})$ 137.8, 135.1, $134.9,133.3,132.0,131.5,131.4,130.4,129.5,129.1,128.4,128.3,128.2,127.9,127.6$, $127.5,127.3,127.1,127.0,126.8,126.3,126.2,125.4,125.0,123.9,120.2,119.5,30.3$; MS (MALDI-TOF) $\mathrm{m} / \mathrm{z}=594.0\left(\mathrm{M}^{+}\right)$; Anal. Calc. for $\mathrm{C}_{32} \mathrm{H}_{18} \mathrm{~S}_{6}: \mathrm{C}, 64.61 ; \mathrm{H}, 3.05$. Found: $\mathrm{C}$, $64.03 ; \mathrm{H}, 3.22$.

X-Ray structure determinations: Details about data collection and solution refinement are given in Table 1. X-ray diffraction measurements were performed on a Bruker Kappa CCD diffractometer, operating with a $\mathrm{Mo}_{\mathrm{K} \alpha}(\lambda=0.71073 \AA)$ X-ray tube with a graphite monochromator. The structures were solved (SHELXS-97) by direct methods and refined (SHELXL-97) by full matrix least-square procedures on $\mathrm{F}^{2}$. All nonhydrogen atoms were refined anisotropically. Hydrogen atoms were introduced at calculated positions (riding model), included in structure factor calculations but not refined. Crystallographic data for the four structures have been deposited with the Cambridge Crystallographic Data Centre, deposition numbers CCDC 916287 (M-3b), CCDC 916288 (P-3b), CCDC 916289 (M-5a), CCDC 916290 (P-5a), CCDC 916291 (rac-6a) and CCDC 916292 (M-6b). These data can be 
obtained free of charge from CCDC, 12 Union road, Cambridge CB2 1EZ, UK (e-mail: deposit@ccdc.cam.ac.uk or http://www.ccdc.cam.ac.uk).

Table 1. Crystal Data and Structure Refinement for $(M)-\mathbf{3 b},(P)-\mathbf{3 b},(M)-\mathbf{5 a},(P)-\mathbf{5 a}, \mathrm{rac}-\mathbf{6} \mathbf{a}$ and $(M)-\mathbf{6 b}$.

\begin{tabular}{|c|c|c|c|c|c|c|}
\hline & $(M)-\mathbf{3 b}$ & $(P)-\mathbf{3 b}$ & $(M)-5 \mathbf{a}$ & $(P)-\mathbf{5 a}$ & $r a c-\mathbf{6 a}$ & $(M)-\mathbf{6 b}$ \\
\hline empirical formula & $\mathrm{C}_{26} \mathrm{H}_{14} \mathrm{Br}_{2}$ & $\mathrm{C}_{26} \mathrm{H}_{14} \mathrm{Br}_{2}$ & $\mathrm{C}_{19} \mathrm{H}_{10} \mathrm{~S}_{3}$ & $\mathrm{C}_{19} \mathrm{H}_{10} \mathrm{~S}_{3}$ & $\mathrm{C}_{24} \mathrm{H}_{14} \mathrm{~S}_{6}$ & $\mathrm{C}_{34} \mathrm{H}_{22} \mathrm{O}_{0.5} \mathrm{~S}_{6}$ \\
\hline fw & 486.19 & 486.19 & 334.45 & 334.45 & 494.71 & 630.88 \\
\hline$T(\mathrm{~K})$ & $293(2)$ & $293(2)$ & $293(2)$ & $293(2)$ & 293(2) & 293(2) \\
\hline cryst syst & orthorhombic & orthorhombic & monoclinic & monoclinic & monoclinic & monoclinic \\
\hline space group & $P 2_{1} 2_{1} 2_{1}$ & $P 2_{1} 2_{1} 2_{1}$ & $P 2_{1}$ & $P 2_{1}$ & $P 2_{1} / \mathrm{n}$ & $C 2$ \\
\hline$a(\AA)$ & $7.4429(4)$ & $7.441(3)$ & $9.9750(7)$ & $9.9769(6)$ & $15.4020(9)$ & $30.5310(5)$ \\
\hline$b(\AA)$ & $13.0429(9)$ & $12.929(12)$ & $3.9145(2)$ & $3.9142(3)$ & $5.9799(3)$ & $7.5614(14)$ \\
\hline$c(\AA)$ & $19.5680(16)$ & $19.73(2)$ & $19.0220(7)$ & $19.0167(10)$ & $24.2610(16)$ & $12.7330(13)$ \\
\hline$\alpha(\operatorname{deg})$ & 90.00 & 90.00 & 90.00 & 90.00 & 90.00 & 90.00 \\
\hline$\beta($ deg $)$ & 90.00 & 90.00 & $95.119(4)$ & $95.104(4)$ & $107.550(5)$ & $95.554(6)$ \\
\hline$\gamma(\operatorname{deg})$ & 90.00 & 90.00 & 90.00 & 90.00 & 90.00 & 90.00 \\
\hline$V\left(\AA^{3}\right)$ & $1899.6(2)$ & $1898(3)$ & $739.79(7)$ & $739.69(87)$ & $2130.5(2)$ & $2925.7(6)$ \\
\hline$Z$ & 4 & 4 & 2 & 2 & 4 & 4 \\
\hline$D_{\mathrm{c}}\left(\mathrm{g} \mathrm{cm}^{-3}\right)$ & 1.700 & 1.702 & 1.501 & 1.502 & 1.542 & 1.432 \\
\hline abs coeff $\left(\mathrm{mm}^{-1}\right)$ & 4.276 & 4.280 & 0.492 & 0.492 & 0.653 & 0.494 \\
\hline GOF on $F^{2}$ & 1.088 & 1.006 & 1.051 & 1.064 & 1.072 & 1.074 \\
\hline $\begin{array}{l}\text { final } R \text { indices }[I \\
>2 \sigma(I)]\end{array}$ & $\begin{array}{l}\mathrm{R} 1=0.0455, \\
\mathrm{wR} 2=0.0657\end{array}$ & $\begin{array}{l}\mathrm{R} 1=0.0710 \\
\mathrm{wR} 2=0.0793\end{array}$ & $\begin{array}{l}\mathrm{R} 1=0.0387, \\
\mathrm{wR} 2=0.0675\end{array}$ & $\begin{array}{l}\mathrm{R} 1=0.0355, \\
\mathrm{wR} 2=0.0632\end{array}$ & $\begin{array}{l}\mathrm{R} 1=0.0398, \\
\mathrm{wR} 2=0.0911\end{array}$ & $\begin{array}{l}\mathrm{R} 1=0.0661, \\
\mathrm{wR} 2=0.1508\end{array}$ \\
\hline $\begin{array}{l}R \text { indices (all } \\
\text { data) }\end{array}$ & $\begin{array}{l}\mathrm{R} 1=0.0771, \\
\mathrm{wR} 2=0.0737\end{array}$ & $\begin{array}{l}\mathrm{R} 1=0.2133, \\
\mathrm{wR} 2=0.1047\end{array}$ & $\begin{array}{l}\mathrm{R} 1=0.0704, \\
w R 2=0.0772\end{array}$ & $\begin{array}{l}\mathrm{R} 1=0.0496 \\
w \mathrm{R} 2=0.0669\end{array}$ & $\begin{array}{l}\mathrm{R} 1=0.0621, \\
\mathrm{wR} 2=0.1059\end{array}$ & $\begin{array}{l}\mathrm{R} 1=0.1097 \\
\mathrm{wR} 2=0.1752\end{array}$ \\
\hline
\end{tabular}

Electrochemical studies: Cyclic voltammetry measurements were performed using a threeelectrode cell equipped with a platinum millielectrode of $0.126 \mathrm{~cm}^{2}$ area, an $\mathrm{Ag} / \mathrm{Ag}^{+}$pseudoreference and a platinum wire counter-electrode. The potential values were then re-adjusted with respect to the saturated calomel electrode (SCE). The electrolytic media involved a 0.1 mol.L $\mathrm{L}^{-1}$ solution of $(n-\mathrm{Bu})_{4} \mathrm{NPF}_{6}$ in $\mathrm{CH}_{2} \mathrm{Cl}_{2}$ (1). All experiments have been performed at room temperature at $0.1 \mathrm{~V} \cdot \mathrm{s}^{-1}$. Experiments have been carried out with an EGG PAR 273A potentiostat with positive feedback compensation.

Chiroptical redox switch by electrochemistry: UV/Vis spectroelectrochemistry (SEC) experiments were performed at $20{ }^{\circ} \mathrm{C}$, under argon, with a home-made Optically Transparent Thin-Layer Electrosynthetic (OTTLE) cell, using a Varian CARY 5000 spectrometer and an EG\&G PAR model 362 potentiostat. A Pt mesh was used as the working electrode, a Pt wire as the counter electrode, and a Pt wire as a pseudo-reference electrode. The electrodes were arranged in the cell such that the Pt mesh was in the optical path of the quartz cell. The anhydrous freeze-pump-thaw degassed sample-electrolyte solution $\left(0.2 \mathrm{M} n\right.$-Bu $\left.\mathrm{Bu}_{4} \mathrm{NPF}_{6}\right)$ was cannula transferred under argon into the cell previously thoroughly deoxygenated. Stable isobestic points were observed during oxidation or reduction. In every case re-reduced or re- 
oxidized samples displayed in the spectral region of interest no features other than those of the parent material.

Theoretical calculations: The optimized geometry, starting from the X-Ray data, has been obtained with the Gaussian09 package at the DFT level of theory. ${ }^{[22]}$ The PBE0 functional has been used. TD-DFT calculations have been performed at the same level of theory on the equilibrium geometry. The rotatory strengths of the transitions, characterizing the circular dichroism spectra, have been determined.

\section{Acknowledgements}

This work was supported by the CNRS, University of Angers and the Ministry of Education and Research (grant to T.B.). I. Freuze and C. Mézière are thanked for the MS analyses.

\section{References}

[1] a) R. H. Martin, Angew. Chem. 1974, 86, 727-738; Angew. Chem. Int. Ed. Engl. 1974, 13, 649-660; b) T. J. Katz, Angew. Chem. 2000, 112, 1997-1999; Angew. Chem. Int. Ed. 2000, 39, 1921-1923; c) A. Urbano, Angew. Chem. 2003, 115, 4116-4119; Angew. Chem. Int. Ed. 2003, 42, 3986-3989.

[2] a) Y. Shen, C.-F. Chen, Chem. Rev. 2012, 112, 1463-1535; b) M. Gingras, G. Félix, R. Peresutti, Chem. Soc. Rev. 2013, DOI: 10.1039/c2cs35111k; c) M. Gingras, Chem. Soc. Rev. 2013, DOI: $10.1039 / \mathrm{c} 2 \mathrm{cs} 35154 \mathrm{~d}$.

[3] For recent examples of heterohelicenes, see: a) J. Míšek, F. Teplý, I. G. Stará, M. Tichý, D. Šaman, I. Císařová, P. Vojtíšek, I. Starý, Angew. Chem. 2008, 120, 3232-3235; Angew. Chem. Int. Ed. 2008, 47, 3188-3191; b) S. Graule, M. Rudolph, N. Vanthuyne, J. Autschbach, C. Roussel, J. Crassous, R. Réau, J. Am. Chem. Soc. 2009, 131, 31833185; c) A. Rajca, M. Pink, S. Xiao, M. Miyasaka, S. Rajca, K. Das, K. Plessel, J. Org. Chem. 2009, 74, 7504-7513; d) J. Guin, C. Besnard, J. Lacour, Org. Lett. 2010, 12, 1748-1751; e) F. Rose-Munch, M. Li, E. Rose, J. C. Daran, A. Bossi, E. Licandro, P. R. Mussini, Organometallics 2012, 31, 92-104; f) J. Zádný, A. Jančařík, A. Andronova, M. Šámal, J. Vacek Chocholoušová, J. Vacek, R. Pohl, D. Šaman, I. Císařová, I. G. Stará, I. Starý, Angew. Chem. 2012, 124, 5959-5963; Angew. Chem. Int. Ed. 2012, 51, 
5857-5861; g) M. Miyasaka, M. Pink, A. Olankitwanit, S. Rajca, A. Rajca, Org. Lett. 2012, 14, 3076-3079; h) A. Ueda, H. Wasa, S. Suzuki, K. Okada, K. Sato, T. Takui, Y. Morita, Angew. Chem. Int. Ed. 2012, 51, 6691-6695; i) K. Yavari, S. Moussa, B. Ben Hassine, P. Retailleau, A. Voituriez, A. Marinetti, Angew. Chem. Int. Ed. 2012, 51, 6748-6752; j) K. Nakano, H. Oyama, Y. Nishimura, S. Nakasako, K. Nozaki, Angew. Chem. Int. Ed. 2012, 51, 695-699; k) Y. Sawada, S. Furumi, A. Takai, M. Takeuchi, K. Noguchi, K. Tanaka, J. Am. Chem. Soc. 2012, 134, 4080-4083; 1) T. Hatakeyama, S. Hashimoto, T. Oba, M. Nakamura, J. Am. Chem. Soc. 2012, 134, 19600-19603.

[4] a) S. Graule, M. Rudolph, W. Shen, J. A. G. Williams, C. Lescop, J. Autschbach, J. Crassous, R. Réau, Chem. Eur. J. 2010, 16, 5976-6005; b) L. Norel, M. Rudolph, N. Vanthuyne, J. A. G. Williams, C. Lescop, C. Roussel, J. Autschbach, J. Crassous, R. Réau, Angew. Chem. Int. Ed. 2010, 49, 99-102; c) E. Anger, M. Rudolph, C. Shen, N. Vanthuyne, L. Toupet, C. Roussel, J. Autschbach, J. Crassous, R. Réau, J. Am. Chem. Soc. 2011, 133, 3800-3803; d) E. Anger, M. Rudolph, L. Norel, S. Zrig, C. Shen, N. Vanthuyne, L. Toupet, J. A. G. Williams, C. Roussel, J. Autschbach, J. Crassous, R. Réau, Chem. Eur. J. 2011, 17, 14178-14198.

[5] a) S. Grimme, J. Harren, A. Sobanski, F. Vogtle, Eur. J. Org. Chem. 1998, 8, 14911509; b) F. Furche, R. Ahlrichs, C. Wachsmann, E. Weber, A. Sobanski, F. Vogtle, S. Grimme, J. Am. Chem. Soc. 2000, 122, 1717-1724; c) J. Autschbach, T. Ziegler, S. J. A. van Gisbergen, E. J. Baerends, J. Chem. Phys. 2002, 116, 6930-6940; d) S. Grimme, Chem. Phys. Lett. 2001, 339, 380-388; e) J. Autschbach, Chirality 2010, 22, E116E152.

[6] a) T. Verbiest, S. Van Elshocht, M. Kauranen, L. Hellemans, J. Snauwaert, C. Nuckolls, T. J. Katz, A. Persoons, Science 1998, 282, 913-915; b) E. Botek, J.-M. André, B. Champagne, T. Verbiest, A. Persoons, J. Chem. Phys. 2005, 122, 234713; b) A. Bossi, E. Licandro, S. Maiorana, C. Rigamonti, S. Righetto, G. R. Stephenson, M. Spassova, E. Botek, B. Champagne, J. Phys. Chem. C 2008, 112, 7900-7907.

[7] a) J. E. Field, G. Muller, J. P. Riehl, D. Venkataraman, J. Am. Chem. Soc. 2003, 125, 11808-11809; b) R. Hassey, E. J. Swain, N. I. Hammer, D. Venkataraman, M. D. Barnes, Science 2006, 314, 1437-1439; c) K. Schmidt, S. Brovelli, V. Coropceanu, D. Beljonne, J. Cornil, C. Bazzini, T. Caronna, R. Tubino, F. Meinardi, Z. Shuai, J.-L. Brédas, J. Phys. Chem. A 2007, 111, 10490-10499; d) T. Kaseyama, S. Furumi, X. Zhang, K. Tanaka, M. Takeuchi, Angew. Chem. Int. Ed. 2011, 50, 3684-3687; e) L. Shi, Z. Liu, G. Dong, L. Duan, Y. Qiu, J. Jia, W. Guo, D. Zhao, D. Cui, X. Tao, Chem. Eur. 
J. 2012, 18, 8092-8099; f) A. Cyphersmith, S. Surampudi, M. J. Casey, K. Jankowski, D. Venkataraman, M. D. Barnes, J. Phys. Chem. A 2012, 116, 5349-5352; g) O. Kel, P. Sherin, N. Mehanna, B. Laleu, J. Lacour, E. Vauthey, Photochem. Photobiol. Sci. 2012, $11,623-631$.

[8] W. N. Herman, Y. Kim, W. L. Cao, J. Goldhar, C. H. Lee, M. M. Green, V. Jain, M. J. Lee, J. Macromol. Sci. Part A 2003, 40, 1369-1982.

[9] T. B. Norsten, A. Peters, R. McDonald, M. Wang, N. R. Branda, J. Am. Chem. Soc. 2001, 123, 7447-7448.

[10] a) J. Nishida, T. Suzuki, M. Ohkita, T. Tsuji, Angew. Chem. Int. Ed. 2001, 40, 32513254; b) E. Ohta, H. Higuchi, H. Kawai, K. Fujiwara, T. Suzuki, Org. Biomol. Chem. 2005, 3, 3024-3031; c) T. Suzuki, Y. Ishigaki, T. Iwai, H. Kawai, K. Fujiwara, H. Ikeda, Y. Kano, K. Mizuno, Chem. Eur. J. 2009, 15, 9434-9441.

[11] a) C. A. Liberko, L. L. Miller, T. J. Katz, L. Liu, J. Am. Chem. Soc. 1993, 115, 24782482; b) L. Adrianssens, L. Severa, T. Šálová, I. Císařová, R. Pohl, D. Šaman, S. V. Rocha, N. S. Finney, L. Pospíšil, P. Slavíček, F. Teplý, Chem. Eur. J. 2009, 15, 10721076.

[12] J. K. Zak, M. Miyasaka, S. Rajca, M. Lapkowski, A. Rajca, J. Am. Chem. Soc. 2010, $132,3246-3247$.

[13] E. Anger, M. Srebro, N. Vanthuyne, L. Toupet, S. Rigaut, C. Roussel, J. Autschbach, J. Crassous, R. Réau, J. Am. Chem. Soc. 2012, 134, 15628-15631.

[14] a) J. L. Segura, N. Martin, Angew. Chem. Int. Ed. 2001, 40, 1372-1401; b) D. Canevet, M. Sallé, G. Zhang, D. Zhang, D. Zhu, Chem. Commun. 2009, 2245-2269.

[15] a) T. Ishiguro, K. Yamaji, G. Saito, Organic Superconductors, Springer-Verlag, Heidelberg, 1998; b) J.-L. Yamada, TTF Chemistry: Fundamentals and Applications of Tetrathiafulvalene, Springer-Verlag, Berlin and Heidelberg, 2004.

[16] N. Avarvari, J. D. Wallis, J. Mater. Chem. 2009, 19, 4061-4076.

[17] F. Riobé, N. Avarvari, Coord. Chem. Rev. 2010, 254, 1523-1533.

[18] a) C. Réthoré, N. Avarvari, E. Canadell, P. Auban-Senzier, M. Fourmigué, J. Am. Chem. Soc. 2005, 127, 5748-5749; b) A. M. Madalan, C. Réthoré, M. Fourmigué, E. Canadell, E. B. Lopes, M. Almeida, P. Auban-Senzier, N. Avarvari, Chem. Eur. J. 2010, $16,528-537$.

[19] G. L. J. A. Rikken, J. Folling, P. Wyder, Phys. Rev. Lett. 2001, 87, 236602.

[20] V. Krstić, G. L .J. A. Rikken, Chem. Phys. Lett. 2002, 364, 51-56. 
[21] J. Jacques, A. Collet, S. H. Wilen, Enantiomers, Racemates and Resolutions, J. Wiley \& Sons, New York, 1981.

[22] Experimental details and characterization of compounds, X-ray data, CV, UV-vis, CD and theoretical calculations details are provided in the Supporting Information. CCDC 916287 ((M)-3b), 916288 ((P)-3b), 916289 ((M)-5a), 916290 ((P)-5a), 916291 ((rac)6a), $916292((M)-6 b)$ contain the supplementary crystallographic data (cif files) for this paper. These data can be obtained free of charge from The Cambridge Crystallographic Data Centre via www.ccdc.cam.ac.uk/data_request/cif.

[23] D. A. Lightner, D. T. Hefelfinger, T. W. Powers, G. W. Frank, K. N. Trueblood, J. Am. Chem. Soc. 1972, 94, 3492-3497.

[24] D. Demeter, P. Blanchard, I. Grosu, J. Roncali, Electrochem. Commun. 2007, 9, 15871591.

[25] S. Grimme, S. D. Peyerimhoff, Chem. Phys. 1996, 204, 411-417.

[26] M.-B. S. Kirketerp, L. A. Espinosa Leal, D. Varsano, A. Rubio, T. J. D. Jørgensen, K. Kilså, M. B. Nielsen, S. B. Nielsen, Chem. Commun. 2011, 47, 6900-6902 
